\title{
SUGGESTIONS FOR IMPROVE THE RURAL WOMEN'S ROLE IN AGRICULTURAL ACTIVITIES IN JAIPUR DISTRICT
}

\author{
SEEMA YADAV ${ }^{*}$, K.C. SHARMA ${ }^{2}$ \& PUSHPA KUMAWAT ${ }^{3}$ \\ ${ }^{I}$ Ph.D. Student, Head, Department of Extension Education, S.K.N. College of Agriculture, SKNAU, Jobner, Jaipur, Rajasthan, \\ India
}

${ }^{2}$ Professor, Head, Department of Extension Education, S.K.N. College of Agriculture, SKNAU, Jobner, Jaipur, Rajasthan, India ${ }^{3} P G$ Student, Head, Department of Extension Education, S.K.N. College of Agriculture, SKNAU, Jobner, Jaipur, Rajasthan, India

\begin{abstract}
In society of India, women have a multi-dimensional role. Women's participation is not bounded to farming activities but also they are doingcrucially in livestock. Rural women have a lead role in development and food security; they are the backbone of the rural economy mainly in the developing world. Rural women play important role in social and economic changes which are essential for sustainable development. But many challenges are face by them because of limited approach to education, health and credit. Empowering rural women is crucial, not for the welfare of individual and families, but also for all inclusive economic development, because women's huge existence in agricultural manpower in the world.Study was derived in Rajasthan's Jaipur district. From this Jaipur district, two panchayat samitis (Jalsu and Dudu) were taken randomly. By using simple random sampling five villages from each determined panchayat samiti were selected.Thus, by proportionate random sampling 120 respondents were selected from these 10 selected villages. The study shows that the foremost suggestion of farm women's was"Organize Adult Education Programmes for farm women". The next was "Increase credit facility for women", followed this "Rural women should be involved in farming related decision making" and the least foremost suggestionwas "Increase facility for exposure visit".
\end{abstract}

KEYWORDS: Suggestions, Role, Agricultural activities, Rural women

Received: Nov 26, 2020; Accepted: Dec 16, 2020; Published: Jan 21, 2021; Paper Id.: IJASRDEC202015

\section{INTRODUCTION}

In society of India, women have a multi-dimensional role. In India greatest numbers of women are involved in agriculture either cultivators or while labourers or while supervisors. Women are the major participants in many farming activities viz.,sowing, weeding, transplanting, threshing, harvesting, manure applying and seeds storage (Chayal, 2010 and Deribe, 2007). Aside from these activities, women are also engaged in all type of livestock activities.Involvement ofwomen in agricultural is apart from domestic work. Contributions given by farm women in agriculture also unaccounted because women are not straight paid. The contribution of women in agriculture is all the time more than the male.Doss (2011) concluded that globally women encompass 43 per cent of the agricultural labour. In food security and development farm women play a main role; they are the backbone of the rural economy mainly in the developing world (ESA, 2011).Rural women play important role in social and economic changes which are essential for sustainable development. But many challenges are face by them because of 
limited approach to education, health and credit. Empowering rural women is crucial, not for the welfare of individual and families, but also for all inclusive economic development, because women's huge existence in agricultural manpower in the world.Access educational facilities for rural women would definitely improve their performance and status in the society.

\section{METHODOLOGY}

Study was derived in Rajasthan's Jaipur district. From this Jaipur district, two panchayat samitis (Jalsu and Dudu) were taken randomly. By using simple random sampling five villages from each determined panchayat samiti were selected. Thus, by proportionate random sampling 120 respondents were selected from these 10 selected villages. Personal interview method was used for data collection. By using MPS the collected data were analysed.

(1) Mean Per cent Score: MPS were achieved by multiplying overall achieved score of the rural women by hundred and divided by the highest achievable score under every statement:

Overall score achieved by the rural women

MPS $=\quad \mathrm{x} 100$

Highest achievable score

\section{RESULT AND DISCUSSIONS}

\subsection{Suggestions of rural women's for improve the role in agricultural activities}

It is showsinTable 1 that the foremost suggestion farm women's was "Organize Adult Education Programmes for farm women" with 87.16 MPS. The nextforemost suggestion was "Increase credit facility for women" with 86.55MPS,after this "Involvement of farm women in decision making related to farming" with 84.33 MPS, "Provide latest technology to the rural women for improve agricultural activities" with 80.66 MPS, "Increase the knowledge about new agricultural activities and agricultural equipment's" with 80.33 MPS, "Rural women's involvement in training programmes to be increased" with 76.33 MPS, "Enhance the contact of rural women with extension personnel" with 70.16 MPS, "Contribution of male members of the family should increase in agriculture activities" with 69.55 MPS, "Increaseinvolvement in social activities" with 62.16 MPS, "For rural women modify the micro credit programme" with 61.33 MPS, "Creating Self Help Group for women empowerment" with 59.66 MPS, "Freedom toexpenses" with 57.55 MPS, "Enhancement of nutrition and health in farm women" with 52.66 MPS "Creating more working opportunities" with 50.55 MPS, "Specific agricultural equipment should improve for farm women" with 49.66MPS "Increase facility for exposure visit" with 43.33 MPS. The probable reason may be thateducation, credit and decision making power improve their role in agriculture by using innovative technology and they would get more benefit. The findings were supported by Awasthi (2000), Linda (2005),Sikarwar (2009), FAO (2011), Owolabiet al. (2011) and Sharma and Badodiya (2016).

\subsection{Suggestions of rural women's for improve the role in agricultural activities in Dudu panchayat samiti}

This revealed in Table 1 that the foremost suggestionof rural women'sin Dudu panchayat samiti was "Organize Adult Education Programmes for farm women" with 87.16 MPS. The second foremost suggestion was "Involvement of farm women in decision making related to farming" with 86.33 MPS,after this "Increase facility of credit for women" with 84.16MPS, "Provide latest technology to the rural women for improve agricultural activities" with 83.16 MPS, "Increase 
the knowledge about new agricultural activities and agricultural equipment" with 73.33 MPS, "Rural women's involvement in training programmes to be increased" with 73.16 MPS, "Enhance the contact of rural women with extension personnel" with 69.16MPS, "Contribution of male members of the family should increase in agriculture activities" with 68.33 MPS, "For rural women modify the micro credit programme " with 66.33 MPS, "Increaseinvolvement in social activities" with 62.16 MPS, "Creating Self Help Group for women empowerment” with 57.16 MPS, "Freedom toexpenses" with 55.33 MPS and "Creating more working opportunities" with 52.66 MPS, "Enhancement of nutrition and health in farm women" with 48.66 MPS, "Specific agricultural equipment should improve for farm women" with 45.16MPS and "Increase facility for exposure visit" with 40.33 MPS.

\subsection{Suggestions of rural women's for improve the role in agricultural activities inJalsu panchayat samiti}

This found in Table 1 that the foremost suggestion of rural women's in Jalsu panchayat samiti was "Increase facility of credit for women" with 89.66 MPS. The second foremost suggestion was "Organize Adult Education Programmes for farm women" with 87.66 MPS, after this"Increase the knowledge about new agricultural activities and agricultural equipment" with 86.33 MPS, “Involvement of farm women in decision making related to farming” with 81.33 MPS, "Rural women's involvement in training programmes to be increased" with 80.16MPS, "Provide latest technology to the rural women for improve agricultural activities" with 78.66 MPS, "Enhance the contact of rural women with extension personnel" with 72.16 MPS, "Contribution of male members of the family should increase in agriculture activities" with 71.33 MPS, "Increaseinvolvement in social activities" with 64.16MPS, "Creating Self Help Group for women empowerment" with 62.16 MPS, "For rural women modify the micro credit programme " with 61.33 MPS, "Freedom toexpenses" 59.16MPS, "Enhancement of nutrition and health in farm women" with 57.16 MPS and "Specific agricultural equipment should improve for farm women" with 55.16MPS, "Creating more working opportunities" with 49.33MPS and "Increase facility for exposure visit" with 45.33 MPS.

Table 1: Suggestions of rural women's for improve their role in agricultural activities

\begin{tabular}{|c|c|c|c|c|c|c|c|}
\hline \multirow[t]{2}{*}{ S.No. } & \multirow[b]{2}{*}{ Suggestions } & \multicolumn{6}{|c|}{ Mean per cent score } \\
\hline & & $\begin{array}{l}\text { Dudu } \\
\text { panchayat } \\
\text { samiti } \\
\mathbf{n}=\mathbf{6 0} \\
\end{array}$ & Rank & $\begin{array}{l}\text { Jalsu } \\
\text { panchayat } \\
\text { samiti } \\
\mathbf{n}=\mathbf{6 0} \\
\end{array}$ & Rank & $\begin{array}{l}\text { Overall } \\
\mathbf{n}=\mathbf{1 2 0}\end{array}$ & Rank \\
\hline 1. & Organize Adult Education Programmes for farm women & 87.16 & 1 & 87.66 & 2 & 87.16 & 1 \\
\hline 2. & $\begin{array}{l}\text { Provide latest technology to the rural women } \\
\text { for improve agricultural activities }\end{array}$ & 83.16 & 4 & 78.66 & 6 & 80.66 & 4 \\
\hline 3. & Creating Self Help Group for women empowerment & 57.16 & 11 & 62.16 & 10 & 59.66 & 11 \\
\hline 4. & Enhancement ofnutrition and health in farm women & 48.66 & 14 & 57.16 & 13 & 52.66 & 13 \\
\hline 5. & $\begin{array}{l}\text { Rural women's involvement in training programmes } \\
\text { to be increased }\end{array}$ & 73.16 & 6 & 80.16 & 5 & 76.33 & 6 \\
\hline 6. & $\begin{array}{l}\text { Involvement of farm women in decision making related } \\
\text { to farming }\end{array}$ & 86.33 & 2 & 81.33 & 4 & 84.33 & 3 \\
\hline 7. & Increase facility for exposure visit & 40.33 & 16 & 45.33 & 16 & 43.33 & 16 \\
\hline 8. & Increase facility of credit for women & 84.16 & 3 & 89.16 & 1 & 86.55 & 2 \\
\hline 9. & Increaseinvolvement in social activities & 62.16 & 10 & 64.66 & 9 & 62.16 & 9 \\
\hline 10. & Freedom to expenses & 55.33 & 12 & 59.16 & 12 & 57.55 & 12 \\
\hline 11. & For rural women modify the micro credit programme & 66.33 & 9 & 61.33 & 11 & 61.33 & 10 \\
\hline 12. & Increase the knowledge about new agricultural activities & 73.33 & 5 & 86.33 & 3 & 80.33 & 5 \\
\hline
\end{tabular}




\begin{tabular}{|c|c|c|c|c|c|c|c|}
\hline & and agricultural equipment & & & & & & \\
\hline 13. & $\begin{array}{l}\text { Enhance the contact of rural women with extension } \\
\text { personnel }\end{array}$ & 69.16 & 7 & 72.16 & 7 & 70.16 & 7 \\
\hline 14. & $\begin{array}{l}\text { Specific agricultural equipment should improve for farm } \\
\text { women }\end{array}$ & 45.16 & 15 & 55.16 & 14 & 49.66 & 15 \\
\hline 15 & Creating more working opportunities & 52.66 & 13 & 49.33 & 15 & 50.55 & 14 \\
\hline \multirow[t]{2}{*}{16} & $\begin{array}{l}\text { Contribution of male members of the family should } \\
\text { increase in agriculture activities }\end{array}$ & 68.33 & 8 & 71.33 & 8 & 69.55 & 8 \\
\hline & Overall & 62.64 & & 69.16 & & 65.90 & \\
\hline
\end{tabular}

\section{CONCLUSIONS}

Our Prime Minister Shri Jawaharlal one time said that, "You can tell the condition of a nation by looking at the status of women". So, we can say that growth and prosperity of any country can be measured by the development and status of its women. Despite such a large involvement, her role and dignity has yet not been recognized. Women status is low by all economic,social and political indicators. So it is essential to providing due acknowledgment to women's work and access to education, credit, technologiesand resources will help to overcome poverty among farm women. The result of the study showed that the suggestions were related to improvement of rural women's social, financial,economicand technological conditions.It is concluded that the foremostrural women's suggestion was "Organize Adult Education Programmes for farm women". The next foremost suggestion was "Increase credit facility for women", followed this "Rural women should be involved in decision making related to farming" and least important suggestion was "Increase facility for exposure visit".

\section{REFERENCES}

1. Agricultural Development Economics (ESA). 2011. The role of women in agriculture. The Food and Agriculture Organization of the United Nations. ESA Working Paper No. 11-02. Available at http://www.fao.org/publications/sofa/en/.

2. Abbasi, S. S., and Q. A. Jafri. "Role of women in crop production in district Pakpattan, Pakistan." International Journal of Agricultural Science and Research (IJASR) 3.3 (2013): 161-170.

3. ANITHA, RONDLA, BHOOPENDRA KUMAR SINGH, and AFIFA JAHAN. "AN EVALUATION OF DRUDGERY REDUCING AGRICULTURAL TECHNOLOGIES DEVELOPED FOR FARM WOMEN." International Journal of Agricultural Science and Research (IJASR) 9. 2, Apr 2019, 35-42

4. Awasthi, H.K., Singh, P.P., Khan, M.A. and Sharma, P.N. (2000). Knowledge and attitude of dairy farmers towards improved dairy practices. Indian Research Journal of Extension. Education. 8(3).

5. ChayalK.,BL Dhaka, and RL Suwalka(2010)Women inagriculture,Humanity\&Social

6. Science. J, 5 (1): 68-72,

7. ChayalK.,BL Dhaka, and RL Suwalka(2010)Women inagriculture,Humanity\&Social

8. Science. J, 5 (1): 68-72,

9. ChayalK.,BL Dhaka, and RL Suwalka(2010)Women inagriculture,Humanity\&Social

10. Science. J, 5 (1): 68-72,

11. ChayalK.,BL Dhaka, and RL Suwalka(2010)Women inagriculture,Humanity\&Social

12. Science. J, 5 (1): 68-72, 
13. Chayal, K.; Dhaka, B.L. and Suwalka, R. L. (2010). Women in agriculture. Journal of Humanity and Social Science. 5(1): 6872 .

14. Deribe Kaske. 2007. Agricultural information networks of farm women and role of agricultural extension: the case of dale woreda, southern nations, nationalities and peoples' region. M.Sc. Thesis. Haramaya University.

15. Doss, C. (2011). The role of women in agriculture. Est. Working,11(2).

16. DIN, TOWSEEF MOHI UD. "HANDICRAFT ENTREPRENEURSHIP: TOOL FOR ECONOMIC DEVELOPMENT IN RURAL ECONOMY." IASET: Journal of Humanities and Social Sciences (IASET: JHSS) 3.1, Jan - Jun 2017; 1-4

17. FAO (2011). Women in Agriculture -Making a Strong Case for Investing in Women. Rome: FAO.

18. Linda, Mayoux, (2005). Women's empowerment through sustainable micro finance: Rethinking best Practice.http//:www.genfinance.Net

19. Owolabi, J.O., Abubakar, B.Z., and Amodu, M.Y. (2011). Assessment of farmer's (women) access to agricultural extension, inputs and credit facility in Sabon-Gari Local Government Area of Kaduna state. Nigerian Journal of Basic Science and Applied Sciences. 19(1): 87-92.

20. PATEL, RM, et al. "DAIRY FARMING PRACTICES: A BETTER WAY TO INVOLVEMENT OF TRIBAL WOMEN IN NARMADA DISTRICT." Small 44: 27-50.

21. Sharma, P. and Badodiya, S.K. (2016). Impact of participation of rural women in agriculture activities. Indian Research Journal Extension Education, 16(2).

22. Sikarwar, (2009). A study on participation of rural women in agriculture activities Ratlam district M.P. M.Sc. (Ag.) Thesis (unpublished), JNKVV, Jabalpur.

23. Suganya, K., R. VELUSAMY, and S. THIYAGESHWARI. "Augmenting the Liquid Waste Management Skills of Rural Shg Women of Madurai District Through Eco-Wash Literacy." International Journal of Agricultural Science and Research (IJASR) 7.4 (2017): 359-362. 

